International Journal of Applied Linguistics \& English Literature

ISSN 2200-3592 (Print), ISSN 2200-3452 (Online)

Vol. 1 No. 5; September 2012 [Special Issue on General Linguistics]

\title{
The Role of Meaning in Translation of Different Subjects
}

\author{
Mohammad Reza Hojat Shamami (PhD student of English Translation) \\ National Academy of Sciences, Armenia \\ Tel: 0037498823592 E-mail: davemrh@yahoo.com
}

Received: 31-07- 2012

doi:10.7575/ijalel.v.1n.5p.247
Accepted: 31-08- 2012

Published: 03-09- 2012

\begin{abstract}
This work is an important consideration of the main issues at the core of meaning and the features of its process. We have seen that even within a single language there are a great variety of ways in which form expresses meaning. Only when a form is being used in its primary meaning or function is there a one - to one correlation between form and meaning each language has its own distinctive forms of representing the meaning. Therefore, in translation the same meaning may have to be expressed in another language by a very different form. To translate the form of one language literally according to the corresponding form in another language would often change the meaning, or at least result in a form which is unnatural in the second language. Meaning must, therefore have priority over form in translation. It is meaning which are to be the linguistic forms.
\end{abstract}

Keywords: Meanings, Antonyms, Reciprocal words, Support Relations

\section{Introduction}

However, as our world is getting more globalize, in the past couple of years we are observing the greatest challenge of text conversion and that is how to find the proper equilibrium between conveying the sense and beauty of the initial text and making the target conversion more efficient and effective(Anderson, 1971). Unless the source language and the receptor language are closely related languages, from the same language family, it is not likely that and the translation. The nature of language is that each language uses different forms and these forms have secondary and figurative meanings which add further complications. A "Word - for - word" translation which follows closely the form of the source language is called a structure of the source text as in an interlinear translation, but a literal translation does not communicate the meaning of the source text (Benjamin, 1989). It is generally no more than a sting of words intended to help someone read a text in its original language. It is unnatural and hard to understand, and may even be quite meaningless, or give a wrong meaning in there receptor language. It can hardly be called a translation (Biguenet, 1989).

\section{Significance of the Research}

It is through the meaning we can claim about all the developments in all kinds of texts and keep abreast of the latest discoveries in the various fields of knowledge, and also have obtain through meaning to the literature of several languages and to the different events happening in the world (Bollinger,1977). This interactive relationship would have been impossible without the knowledge of the various languages spoken by the different communities and nations. This is how human beings realized the importance of meaning in different languages long ago (Brower, 1959).

\section{Kinds of Meaning}

People usually think of meaning as something to which a word or sentence refers. For example, the word apple refers to the fruit produced by a certain tree (Catford, 1965). People know the meaning of apple because they have seen an apple and learned to call it apple. This kind of meaning is called Referential meaning because the word refers to a certain thing, event, attribution, or relation which person can perceive or imagine. A sentence has meaning because it refers to something that happened, or may happen, or is imagined as happening. Referential meaning because the word refers to a certain thing event, attribution, or relation which a person can perceive or imagine. A sentence has meaning because it refers to something that happened, or may happen or is imagined as happening. Referential meaning is what the communication is a bout. It is the information content (Chafe, 1970). The Referential meaning is organized into a semantic structure. The information bits are" packaged " that is, they are put together and expressed by a variety of combinations. As they are " packaged " into larger and larger units 
International Journal of Applied Linguistics \& English Literature

ISSN 2200-3592 (Print), ISSN 2200-3452 (Online)

Vol. 1 No. 5; September 2012 [Special Issue on General Linguistics]

there is Organizational meaning in the discourse which must also be taken into account in the translation. may be the topic be old information, some new certain information may be the topic (what is being talked about) of the discourse, other information commenting on the topic, and some information may be more central to the message, that is more important or more prominent (Gumperz, 1982). The two propositions Mary peeled an apple and Mary ate an apple include Mary as the agent and Apple as the affected in both propositions. Mary and Apple are both referred to twice (Referential meaning). But in order to form a correct grammatical structure, we must also know if the Organizational meaning includes the fact that there is only one Mary and only one Apple or if there are two Marys or two Apples. If they are the same, the surface structure in English would be a form like Mary peeled an apple. And then she ate it. After the first proposition is given. Mary and Apple are both old information and so pronominal forms are used (Fleming, 1972).

Where the communication takes place, when it takes place, the age, sex, and social status of the speaker and hearer, the relationship between them the presuppositions that each brings to the communication, the cultural background of the speaker and the addressee, and many other situational matters result in Situational meaning. For example, they very same person may be referred to by various lexical items. A man named John Smith may be referred to as John Mr. Smith, Professor Smith, etc. depending on the situation. This choice carries Situational meaning. It may indicate whether the situation is formal or informal. A friend who fevers to him as John as he greets him in the morning may later in the day call him Professor Smith when introducing him at a university seminar. Different lexical forms will be chosen to indicate Situational meaning (Cook, 1971).

\subsection{Implicit Referential Meaning}

All language has grammatical form which is obligatory but languages differ in what is obligatory. For example, in English, it is obligatory to make explicit whether a noun is singular or plural. One cannot say, "I saw dog walking down street. " One must say "I saw some dogs walking down the street.". Or "I saw a dog walking down the street. " Number must be made explicit in English, but in many languages it can be left implicit. Nouns which refer to events contain implicit information. Since a noun form is used, there is no indication of who the agent and affected are. The sentence " Help will come " has no subject or object verbs to describe this event, the subject and object would need to be supplied, that is a form something like the following: Someone will come and he they will help us (Austin, 1962).

\subsection{Implicit information and Organizational Meaning}

A text is a unit. It is organized in some logical way. It is characterized by cohesion, continuity, grouping and patterns of prominence, there is a flow of old and new information redundancy which helps signal the unity and various ways to indicate the topic or theme of the text but languages differ in how these matters are indicated. One language may use pronominal forms a great deal and another may have an abundance of pro - verbal forms. One may have clear markers of which events make up the backbone of the story. Another may rely on chronological order (Austin, 1962).

\subsection{Implicit Situational Meaning}

Information which is left implicit when talking to one person might be made explicit when talking to another. A woman might say to her husband, "Peter is sick. " In reporting the same information to the doctor she would say, "My son Peter is sick. " Or "My son is sick". The information may son was not needed to identify Peter when talking to her husband who knew very well who Peter was. Often in normal conversation, there is much which is going on in the situation which makes it possible to understand exactly what is meant without using many words. For example, a mother, seeing her child about to put his hand in the fire, cries out, "No " The child understands the message, "Don't put your hand in the fire" All of this information is carried by one word "No " might mean something very different, as when used to answer the question, Did you go to town today? In that case, the implied information is not found in the situation but in the question which had been asked, that is, in the linguistic context. It is quite possible for person from one culture to read a story written about a happening in another culture and not understand the story at all because so much information is left implicit. The story teller had not made this information explicit because everyone in the culture knew who did what at the festival he was describing. The language structure did not make it necessary to include this information, and since the common culture supplied it to his audience, it was left implicit. However, a translation into Portuguese required that the information be made explicit if the story was to be understood. In order to adequately determine the meaning of the text, one must know the situational setting of the communication (Ahrens, 1971). 
International Journal of Applied Linguistics \& English Literature

ISSN 2200-3592 (Print), ISSN 2200-3452 (Online)

Vol. 1 No. 5; September 2012 [Special Issue on General Linguistics]

One of the challenges facing a translator knows when to supply the information which is implicit in the text. The author may have written for people with the same culture and same experiences as his. But the translator, or those whom he would like to read his translation, may not have this background and may not know much of this implied information. They may not be able to understand his translation unless he makes some of this implicit information from the communication situation explicit. As will be discussed in much more detail later, the translator does not want to add information which is not part the text he is translating. There is a difference between implicit information and information which is simply absent and never intended to be part of the communication (Crowell, 1973). For instance, in the example "My son Peter is sick, " the mother did not say "peter has brown hair and is ten years old. This is not implied. It is absent. It is not part of the communication and, therefore, should not be added. If a person wrote, "John made the Queen's list" he is assuming that the readers know that the Queen of England is indicated. However, for an audience that did not know this fact and had never heard of the Queen, much less her list, the implied information would need to be added. It is not absent, it is implied, and part of the communication situation. The translation may have to be as explicit as to state, "John made the Queen of England's yearly. Honors list. " Implicit information needs to be added only when it is necessary to communicate correct meaning or to insure naturalness of form in the receptor language translation (Dik Simon, 1980). It will sometimes need to be made explicit because the source language writer and his audience shared information which is not shared by the receptor language audience.

\subsection{Antonyms}

The antonym of a word is the exact opposite, or contrasts in some particular part of its meaning. All language will have pairs of words which are antonyms. But different language will have different sets. For example, in English we distinguish short and tall vertically and short and long horizontally. In Aguaruna, there are only two words sutajuch and esajam which are used for both the vertical and horizontal distinction of length. In English, we have the words well and bad which are antonyms. In Aguaruna, the distinction is made by the word good, pegkeg, contrasting with the same word good linked to a negative suffix, not - good, pegkegchau. That is there are not two separate words, there is simply good and not good. Some language will have words for slave and free. Others will simply have a word for free while the meaning for "slave " will be not free. It can sometimes be very helpful to a translator who is looking for a particular word to realize that if the thinks about the antonym, the word opposite in meaning, he may be able to find the desired word by constructing a negative form of the antonym.' In some instances a receptor language may already use a construction with negatives as a normal way of handling certain positive concepts. In Bila' an of the Philippines. The expression it is not possible we will not is how we must is expressed " (Nida, 1964).

\section{Reciprocal words}

Most languages will also have sets of words which are the reciprocal of one another. For example, the words give and receive have a reciprocal relationship to one another. One can say, "John gave Mary a book." Or one can say. "May receive a book from John". The meaning is the same since the two actions are reciprocal actions. One can say "John taught Bill, " or " Bill learned from John. "Teach and learn are reciprocal actions. This may sometimes be very helpful in translation where the receptor language does not have a specific word used in the same way as the source language. It may be that the same meaning can be communicated by using a reciprocal word. For example, the government gave a large grant to the miners, might in some translation need to be translated conversely; the miners received a large grant from the government (Wittgenstein, 1953).

\section{Addition and Support Relations}

In the preceding section, the analysis of a text into propositions was discussed and illustrated. However, a text does not consist of a long list of propositions only. This proposition group together into larger and larger units. It was noted that meaning components units to form concepts, concepts unite to form concept clusters, and concept clusters unite to form propositions. In narrative texts, for example, propositions unite to form propositional clusters, these clusters unite to form semantic paragraphs, semantic paragraphs unite to form episodes, episodes unite to form episode clusters, episode clusters unite into parts and these unite to form a discourse. The number of levels of groupings will depend on the length, type, and complexity of the text. Not all levels occur in each text. The names for groups will vary with the different discourse types. It is the idea of grouping that is important to understand (Buchwald, 1993).

\section{Chronological and No Chronological}

Another classification of communication relations which is important to understand is the difference between chronological and no chronological relations. Those relations in which the propositions are related to each other in 
International Journal of Applied Linguistics \& English Literature

ISSN 2200-3592 (Print), ISSN 2200-3452 (Online)

Vol. 1 No. 5; September 2012 [Special Issue on General Linguistics]

terms of time are said to be chronological relations. Where the time element is not focal in the relationship the relations are labeled as no chronological. In the examples above, the first one about John has for propositions which are relation chronologically, that is first John went home then he ate supper, then he did his homework and finally he went to bed. These are in chronological sequence that is there is an element of time in the relation between them. However, in the second illustration, Mary swept the floor is the result of the reason; the floor was dirty (Donald, 1975). Causality is the focal relationship. Since time is incidental and not focal the relation is classified as no chronological. It is true, however that the reason usually precedes the result in time of occurrence in the happening being recorded in the text. In a larger discourse for example, there may be a series of paragraphs each one describing an event which leads up to a final major event. These paragraphs would then be in a relation of progression to the head paragraph which would be the goal. The relations, sequential, simultaneous and progression are commonly found in narrative and procedural discourses (Nida, 1964).

\section{Results and Discussions}

A study of dictionary will indicate the amazing " a packaging" of meaning components in lexical items. One single word means watch sheep by night. All of those components are in a single lexical item. In Vietnamese, there is a word which means someone leaves to go somewhere and something happens at home so that he has to go back home(Crowell, 1973). Many times a single word in the source language will need to be translated by several words. It is characteristic of languages that the same meaning component will occur in several surface structure lexical items (forms). In English, the word sheep occurs. However, the words lamb, additional meaning components of young (in lamb), it is further characteristic of languages that one form will be used to represent several alternative meanings. This again is obvious from looking in any good dictionary (Fleming, 1972).

\section{Conclusion}

Each language has its own distinctive forms of representing the meaning. Therefore, in translation the same meaning may have to be expressed in another language by a very different form. To translate the form of one language literally according to the corresponding form in another language would often change the meaning, or at least result in a form which is unnatural in the second language.

\section{References}

Ahrens, T. (1977). Concepts of Power in Melanesian and Biblical perspective. Musicology. 141P.

Anderson, S. R. (1971). On the Role of Deep. Structure in Semantic Interpretation. Foundations of Language.

219p.

Austin, K. L. (1962). How to Do Things with word. New York: Oxford University Press.

Benjamin, A. (1989). Translation and the Nature of Philosophy. London and New York: Rutledge. 342p.

Biguenet, J. (1989). The Craft of translation Chicago: University of Chicago press.

Bollinger, D. (1977). Meaning and Form. London: Longman.

Brower, R. A. (1959). On Translation. Cambridge: Harvard University Press.

Buchwald, J. (1993). Design for Experimenting. World Changes. Harwich. Cambridge: University Press.

Catford, J.C. (1965). A Linguistic Theory of Translation. London: Oxford University Press. 103P.

Chafe, W. L. (1970). Meaning and the Structure of Language. Chicago:The University of Chicago press.

Cook, W. A. (1971). Case Grammar as a Deep Structure in Tagmemic Analysis. Languages and linguistics

working papers. Washington DC: Georgetown University.

Crowell, T. H. (1973). Cohesion in Bororo Discourse. Linguistics. The Hague: Mouton. 104P.

Derrida, J. (1982). White Mythology. Metaphor in the Text of Philosophy: The Harvester Press Ltd.

Dik, S. C. (1980). Studies in Functional Grammar. New York: Academic Press.

Donald, B. (1975). Machine Translation of Languages. New York: The Massachusetts Institute of Technology and John Wiley and Sons. 135P.

Fleming, I. (1972). Logical Relationships. Instructions for the Preparation of Data Relevant for the Analysis of Serological Constructions and their Grammatical Realizations. Settle. Summer Institute of Linguistics.

Gumperz, J. J. (1982). Language and Social Identity. Cambridge-New York: Cambridge University Press. 272P.

Langer, S. K. (1951). Philosophy in a New Key. New York: New American Library. 256P.

Nida, E. A. (1964). Toward a Science of Translating. Leiden. Brill. 331P.

Ricoeur, P. (1969). Le Conflit des interprétations: essais d herméneutique. Paris: Éditions du Seuil. 505p.

Wittgensteinl,J. (1953). Philosophical Investigations. New York. Macmillan. Oxford. Blackwell. 232P. 